\title{
Kualitas Pelayanan Publik dalam Pembuatan SIM di Era Covid-19 pada Polrestabes Bandung Tahun 2020
}

\section{Quality of Public Service in Making SIM in the Covid-19 Era at Bandung Police Station in 2020}

\author{
1Fitriyana Putri Fadhillah, ${ }^{2}$ Nanang Suparman \\ 1,2 Prodi Administrasi Publik, Universitas Islam Negeri Sunan Gunung Djati Bandung, Indonesia
}

Disetujui: Oktober 2021; Direview: Nopember 2021;Diterima: Nopember 2021

\begin{abstract}
Abstrak
Di tengah pandemi Covid-19 pada tahun 2020, Satuan Penyelenggara Administrasi SIM (Satpas) Polrestabes Bandung dalam pelayanan Surat Izin Mengemudi (SIM) mengalami penurunan nilai indeks evaluasi pelayanan SIM, jumlah pembuatan SIM, kapasitas gedung karena pandemi Covid-19 yang mengharuskan physical distancing, dan kurangnya sosialisasi terhadap informasi pembatasan waktu pendaftaran pembuatan SIM, serta sarana prasarana lahan parkir yang belum tertata dengan rapi dan baik. Tujuan penelitian ini untuk mengetahui kualitas pelayanan publik dalam pembuatan Surat Izin Mengemudi (SIM) di era Covid-19 pada Polrestabes Bandung tahun 2020. Metode penelitian yang digunakan yakni deskriptif dengan pendekatan kualitatif. Teknik pengumpulan data yang digunakan yaitu observasi, wawancara, dokumentasi, dan bahan audio-visual. Hasil penelitian menujukan bahwa dimensi assurance (jaminan) belum optimal, dimana Satpas Polrestabes Bandung tidak bisa memberikan jaminan ketepatan waktu sesuai dengan yang tercantum dalam standar pelayanan. Hal tersebut dikarenakan melihat dari banyaknya atau jumlah pemohon SIM yang membutuhkan pelayanan dan sistem yang bekerja dari pusat online atau offline, sehingga dapat mempengaruhi responsiviness (daya tanggap) dalam memberikan pelayanan yang cepat.
\end{abstract}

Kata Kunci: Kualitas Pelayanan Publik, SIM, Polrestabes Bandung, Covid-19

\begin{abstract}
In the midst of the Covid-19 pandemic in 2020, Satuan Penyelenggara Administrasi SIM (Satpas) Polrestabes Bandung in the service of a Driving License (SIM) experienced a decrease in the value of the SIM service evaluation index, the number of SIM manufacturers, the capacity of building due to the Covid-19 pandemic which required physical distancing, and the lack of socialization of information Restrictionss on registration time for making a SIM, as well as parking facilities that have not been arranged neatly and well. The purpose of this study was to determine the quality of public services in making a Driving License (SIM) in the Covid-19 era at Polrestabes Bandung in 2020. The research method used was descriptive with a qualitative approach. Data collection techniques used are observation, interviews, documentation, and audio-visual materials. The results of the study indicate that the assurance dimension is not optimal, where Satpas Polrestabes Bandung cannot guarantee timeliness in accordance with what is stated in the service standard. This is because seeing from the number or number of SIM applicants who need services and systems that work from online or offline centers so that can affect responsiveness (responsiveness) in providing fast service.
\end{abstract}

Keywords: Quality of Public Service, SIM, Polrestabes Bandung, Covid-19

How to Cite : Fadhillah, F.P., \& Suparman, N. (2021). Kualitas Pelayanan Publik dalam Pembuatan SIM di Era Covid19 pada Polrestabes Bandung Tahun 2020. PUBLIKAUMA: Jurnal Ilmu Administrasi Publik UMA, Vol. 9 (2): 25

*Corresponding author:

ISSN 2549-1660 (Print)

E-mail: fitrivanaputrif@gmail.com

ISSN 2580-2011 (Online) 


\section{PENDAHULUAN}

Adanya pandemi virus Covid-19, mengharuskan Pemerintah Indonesia untuk mengeluarkan kebijakan Pembatasan Sosial Berskala Besar (PSBB) dan penerapan protokol kesehatan dalam rangka pencegahan penyebaran virus tersebut (Suparman, 2021). Adapun pada perkembangannya, di Kota Bandung kemudian menerapkan Adaptasi Kebiasaan Baru (AKB) atau dikenal dengan sebutan new normal. Sebagaimana hal tersebut dirumuskan dalam Peraturan Wali Kota Bandung No. 37 Tahun 2020 tentang Pedoman Pelaksanaan Adaptasi Kebiasaan Baru dalam Rangka Pencegahan dan Pengendalian Covid19.

Sejalan dengan hal tersebut, Polrestabes Bandung sebagai unsur pelaksana tugas kewilayahan yang berada dibawah naungan Kepolisian Daerah Jawa Barat tetap memberikan pelayanan kepada masyarakat ditengah pandemi Covid-19, salah satunya adalah pelayanan pembuatan SIM dengan adanya pembatasan pemohon SIM (Bandung Berita, 2020). Berdasarkan observasi yang peneliti lakukan ditemukan permasalahan penelitian yakni penurunan pengajuan pembuatan dan/atau perpanjangan SIM di Satpas Polrestabes Bandung sebagai dampak pandemi Covid-19 yaitu

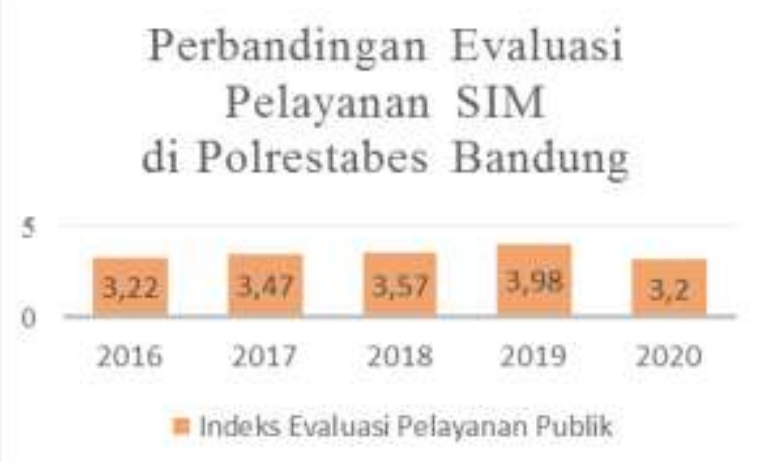

Gambar 1. Perbandingan Evaluasi Pelayanan SIM

Sumber: Polrestabes Bandung 2016-2020

Adanya penurunan nilai indeks evaluasi pelayanan SIM yang signifikan di Polrestabes Bandung. Sebagaimana dalam Gambar 1, bahwa nilai indeks dalam evaluasi pelayanan SIM di Polrestabes Bandung dari tahun 2016 hingga tahun 2019 selalu mengalami peningkatan. Akan tetapi, di tahun 2020 mengalami penurunan yang signifikan sebesar
0,78. Faktor penurunan daya beli masyarakat akibat pandemi Covid-19 menjadi salah satu penyebab menurunnya minat untuk membuat SIM.

Tabel 1 Perkembangan Pembuatan SIM Polrestabes Bandung

\begin{tabular}{lllll}
\multirow{2}{*}{ NO. } & \multirow{2}{*}{ TAHUN } & JENIS SIM & \\
\cline { 3 - 5 } & & $\mathrm{A}$ & $\mathrm{C}$ & $\mathrm{D}$ \\
\hline 1. & 2016 & 34.549 & 48.574 & 35 \\
\hline 2. & 2017 & 36.376 & 57.619 & 43 \\
\hline 3. & 2018 & 34.220 & 53.347 & 38 \\
\hline 4. & 2019 & 35.469 & 55.004 & 50 \\
\hline 5. & 2020 & 27.488 & 38.582 & 48 \\
\hline JUMLAH TOTAL & 168.102 & 253.126 & 214 \\
\hline
\end{tabular}

Sumber: Polrestabes Bandung

Terjadinya penurunan jumlah pembuatan SIM pada tahun 2020. Terlihat dalam Tabel 2, bahwa angka penerbitan SIM di Polrestabes Bandung mengalami naik turun atau bersifat fluktuatif dari tahun 2016 hingga tahun 2020. Pada tahun 2020 angka penerbitan SIM untuk jenis SIM A, SIM C, dan SIM D mengalami penurunan dari tahun sebelumnya yang mana hal ini disebabkan oleh pandemi Covid-19. Selain itu, kapasitas gedung atau ruang tunggu yang berkurang akibat pandemi Covid-19 yang mewajibkan untuk melakukan physical distancing. Dimana sebelum adanya pandemi, gedung Satpas Polrestabes Bandung dapat menampung kurang lebih 150 orang atau pemohon SIM dan kini hanya dapat menampung setengah atau $50 \%$ dari jumlah yang dapat ditampung sebelum pandemi. Sementara itu, pemberdayaan SDM Polterstabes dalam menangani pelayanan SIM sebelum dengan sesudah pandemi Covid-19 tidak mengalami perubahan masih dengan pendekatan lama.

Kurangnya sosialisasi yang dilakukan Polrestabes Bandung terhadap informasi pembatasan waktu pendaftaran saat pandemi Covid-19. Hal ini menyebabkan tidak sedikit dari pemohon SIM yang kecewa dikarenakan tidak mengetahui bahwa ada pembatasan waktu pendaftaran. Lalu berdasarkan Laporan Kegiatan Asistensi dan Monitoring Pelayanan Publik Tim Deputi Pelayanan Publik Kementrian PANRB di Polrestabes Bandung pada bulan Oktober 2020, hasil yang dicapai dari kegiatan tersebut masih ditemukan adanya kekurangan pada sarana prasarana lahan parkir yang belum tertata dengan baik 
dan rapi khususnya bagi pemohon yang membawa kendaraan roda empat. Hal tersebut dikarenakan keterbatasan lahan parkir yang ada di lingkungan Polrestabes Bandung.

Sebagaimana permasalahan di atas, semestinya pelayanan publik yang diharapkan oleh masyarakat selaku pengguna layanan adalah pelayanan yang tepat, cepat, mudah, aman, pelayanan well-informed, tidak berbelitbelit, adanya jaminan (waktu-biaya-hukum), responsif, konsisten, akomodatif dan tidak adanya pungutan liar (Suparman, 2017). Lembaga Administrasi Negara (LAN) menjelaskan bahwa suatu pelayanan dikatakan berkualitas, jika hasil dari pelayanan publik baik barang atau jasa tersebut dapat memenuhi harapan dan kebutuhan masyarakat (Handoyo, 2012).

Penulis menggunakan teori kualitas pelayanan publik menurut Zeithaml (1990) (Hardiansyah, 2018) sebagai acuan untuk mengukur berkualitasnya suatu pelayanan yang diberikan oleh Satpas Polrestabes Bandung. Adapun untuk menentukan baik buruknya kualitas pelayanan publik dapat diukur melalui lima dimensi yang diantaranya adalah:

Tangible (Berwujud)

Keterwujudukan merupakan salah satu aspek yang berkenaan dengan lingkungan fisik (Hiplunudin, 2017). Pada dimensi ini, dalam memberikan pelayanan harus memperhatikan penampilan saat melayani, sarana prasarana serta fasilitas pendukung pelayanan, komunikasi dan kemudahan dalam akses serta proses pelayanan. Temuan di lapangan bahwa loket pelayanan pembuatan SIM yang tersedia tidak sebanding dengan jumlah pemohon dan alat simulator pengujian berkendara dinilai tidak layak oleh pemohon.

Reliability (Kehandalan)

Kehandalan mencerminkan kinerja aparatur pemerintah dalam melayani masyarakat sesuai dengan standar pelayanan yang ada dan keahlian petugas dalam menggunakan instrumen pada proses pelayanan.

Responsiviness (Daya Tanggap)

Dimensi ini meliputi ketanggapan aparatur dalam memberikan pelayanan yang cepat dan tepat serta tanggap dalam menanggapi pengaduan dari masyarakat.

\section{Assurance (Jaminan)}

Jaminan merupakan sikap pemberi layanan untuk dapat menumbuhkan rasa aman dan kepercayaan atas pelayanan yang diberikan. Selain itu, adanya kepastian waktu, biaya, dan legalitas pelayanan.

\section{Empathy (Empati)}

Pemberi pelayanan dapat melayani dengan ramah, memberikan perhatian pada setiap penerima pelayanan, seta mendahulukan kepentingan penerima pelayanan.

Terdapat penelitian serupa terkait dengan kualitas pelayanan publik dalam pembuatan SIM, seperti penelitian terdahulu yang membahas mengenai kualitas pelayanan terhadap kepuasan pelanggan dalam pembuatan SIM (Yunita, 2018) dan (Putri, 2017). Adapun penelitian terdahulu yang membahas tentang kualitas pelayanan publik dengan fokus penelitian pada tahun 2015 dan berbeda objek penelitiannya dilakukan oleh (Rasuanto, 2018) dan (Sarmini, 2019). Keseluruhan penelitian terdahulu tersebut melakukan penelitian pada saat kondisi normal atau belum adanya pandemi Covid-19. Sedangkan pada penelitian ini, dilakukan dengan kondisi luar biasa yakni ditengah pandemi Covid-19. Dimana mengharuskan untuk seluruh masyarakat menaati protokol kesehatan begitu pun dalam memberikan pelayanan. Sejalan dengan penelitian (Putra, 2021), bahwa penyebaran wabah Covid-19 yang begitu cepat di Indonesia memberikan pengaruh negatif terhadap angka pembuatan SIM C khususnya di Kota Pontianak, Provinsi Kalimantan Barat.

Berdasarkan fenomena, dan uraian empiris serta teoritis, tujuan penelitian ini yaitu untuk mengetahui kualitas pelayanan publik dalam pembuatan Surat Izin Mengemudi (SIM) di era Covid-19 pada Polrestabes Bandung tahun 2020.

\section{METODE PENELITIAN}

Penelitian ini menggunakan metode penelitian deskriptif dengan pendekatan kualitatif (Creswell, 2019), alasan menggunakan metode ini relevan dengan karakteristik masalah yang akan diteliti yang bertujuan untuk memahami, mengetahui, dan 
mengungkapkan sebuah kondisi atau fenomena secara detail dan mendalam terkait kualitas pelayanan SIM ditengah pandemi Covid-19 (Suparman, 2021). Penelitian kualitatif merupakan sebuah prosedur untuk mengkaji dan menganalisis makna yang diperoleh dari beberapa individu ataupun sekelompok individu diasumsukan bersumber dari fenomena sosial (Creswell, 2019).

Tabel 2 Informan Penelitian

\begin{tabular}{|c|c|c|c|c|}
\hline No & $\begin{array}{l}\text { Tanggal } \\
\text { Wawancar } \\
\text { a }\end{array}$ & $\begin{array}{l}\text { Rincia } \\
\mathrm{n}\end{array}$ & Nama & $\begin{array}{l}\text { Keterang } \\
\text { an }\end{array}$ \\
\hline 1. & $\begin{array}{l}23 \text { April } \\
2021\end{array}$ & $\begin{array}{l}\text { Infor } \\
\text { man } 1\end{array}$ & $\begin{array}{l}\text { IPTU } \\
\text { Yulianti, } \\
\text { S.H., M.H. }\end{array}$ & $\begin{array}{l}\text { Kasubnit } \\
\text { I Regident }\end{array}$ \\
\hline 2. & $\begin{array}{l}29 \text { April } \\
2021\end{array}$ & $\begin{array}{l}\text { Infor } \\
\text { man } 2\end{array}$ & $\begin{array}{l}\text { Briptu } \\
\text { Maya }\end{array}$ & $\begin{array}{l}\text { Petugas } \\
\text { Teknis } 1\end{array}$ \\
\hline 3. & $\begin{array}{l}29 \\
2021\end{array}$ & $\begin{array}{l}\text { Infor } \\
\text { man } 3\end{array}$ & $\begin{array}{l}\text { Briptu } \\
\text { Yulianti } \\
\text { Rahmawa } \\
\text { ti }\end{array}$ & $\begin{array}{l}\text { Petugas } \\
\text { Teknis } 2\end{array}$ \\
\hline 4. & $\begin{array}{ll}6 & \text { Mei } \\
2021 & \end{array}$ & $\begin{array}{l}\text { Infor } \\
\text { man } 4\end{array}$ & $\begin{array}{l}\text { Briptu } \\
\text { Agus } \\
\text { Saeful } \\
\text { Bahrie } \\
\end{array}$ & $\begin{array}{l}\text { Petugas } \\
\text { Teknis } 3\end{array}$ \\
\hline 5. & $\begin{array}{l}26 \text { April } \\
2021\end{array}$ & $\begin{array}{l}\text { Infor } \\
\text { man } 5\end{array}$ & $\begin{array}{l}\text { Wildan Al } \\
\text { Hakim }\end{array}$ & $\begin{array}{l}\text { Pemohon } \\
\text { SIM } 1\end{array}$ \\
\hline 6. & $\begin{array}{ll}6 & \text { Mei } \\
2021 & \end{array}$ & $\begin{array}{l}\text { Infor } \\
\text { man } 6\end{array}$ & $\begin{array}{l}\text { Reni } \\
\text { Nurhaera } \\
\text { ni }\end{array}$ & $\begin{array}{l}\text { Pemohon } \\
\text { SIM } 2\end{array}$ \\
\hline 7. & $\begin{array}{ll}10 & \text { Mei } \\
2021 & \end{array}$ & $\begin{array}{l}\text { Infor } \\
\text { man } 7\end{array}$ & $\begin{array}{l}\text { Ayu } \\
\text { Mentari }\end{array}$ & $\begin{array}{l}\text { Pemohon } \\
\text { SIM } 3\end{array}$ \\
\hline
\end{tabular}

Sumber: Diolah oleh Peneliti, Tahun 2021

Teknik pengumpulan data pada penelitian ini melalui observasi, wawancara, dokumentasi, dan bahan audio-visual. Pada wawancara, informan penelitian ditentukan dengan purposive sampling. Adapun teknik analisis data yang melalui beberapa tahapan yakni manajemen data; membaca dan membuat memo (memoing); deskripsi, klasifikasi, dan penafsiran; serta penyajian dan interpretasi data. Selain itu, teknik yang digunakan dalam mengukur keabsahan data dengan triangulasi sumber yakni membandingkan fenomena lapangan penelitian dan triangulasi teknik yakni pengecekan data kepada sumber yang sama dengan teknik yang berbeda pengumpulan data dengan memeriksa kemudian membandingkan data yang diperoleh peneliti.

\section{HASIL DAN PEMBAHASAN}

Sasaran pelayanan Satpas Polrestabes Bandung dalam masa Adaptasi Kebiasaan Baru Pandemi Covid-19 (Satlantas Polrestabes Bandung, 2021), yaitu:

Terwujudnya postur Personel Polri khususnya Polisi berseragam (Registrasi dan Identifikasi Pengemudi SIM Satpas Satlantas Polrestabes Bandung) sebagai pelopor physical distancing dan social distancing di ruang publik.

Terbentuknya sistem pelayanan Registrasi dan Identifikasi Pengemudi SIM yang telah melaksanakan Protokol Kesehatan dalam bidang pelayanan publik berupa penggunaan masker dan sarung tangan bagi petugas pelayanan pada masa Adaptasi Kebiasaan Baru.

\section{Tangible (Berwujud)}

Dalam menilai kualitas pelayanan publik dilihat dari sarana fisik perkantoran, ruang tunggu, komputerasi administrasi dan tempat informasi (Taufiqurokhman \& Satispi, 2018). Adapun yang menjadi indikator dari dimensi keterwujudan ini diantaranya meliputi penampilan petugas, sarana prasarana, kemudahan dalam akses dan proses pelayanan, komunikasi, serta instrumen pada proses pelayanan (Hardiansyah, 2018).

Berdasarkan hasil wawancara dengan informan pembuat SIM baru, ia mengatakan: ".....dilihat dari penampilan petugas pelayanan di Satpas Polrestabes Bandung...ya sudah sesuai dengan standar operasional prosedur dan mengikuti protokol kesehatan dengan menggunakan masker, face shield, dan sarung tangan." Informan berikutnya pemohon perpanjangan SIM, mengatakan: “... ehm kalo...sarana prasarana serta fasilitas penunjang pelayanan.... sudah layak." Berdasarkan pengamatan peneliti sarana pelayanan seperti ruang tunggu yang telah tersedia dengan diberi batasan atau tanda silang sebagai bentuk physical distancing terlihat pada Gambar 2, ruang bermain anak, tempat charger handphone, ruang laktasi untuk ibu menyusui, dan toilet. 


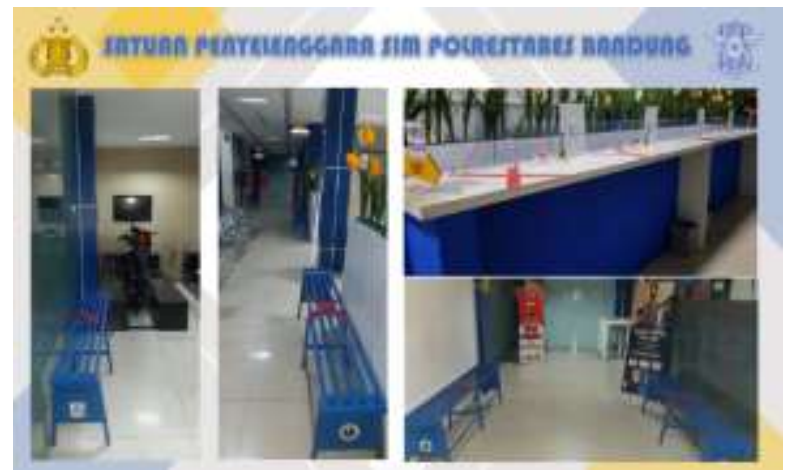

Gambar 2 Pembatasan Sosial di Polrestabes Bandung

Sumber: Polrestabes Bandung, Tahun 2021

Selain itu, fasilitas untuk penyandang disabilitas di Satpas Polrestabes Bandung sudah cukup memadai. Sebagaimana hal tersebut sejalan dengan yang disampaikan oleh Deputi Bidang Pelayanan Publik Kementrian Pendayagunaan Aparatur Negara dan Reformasi Birokrasi (PANRB), agar setiap unit pelayanan khususnya Polri dalam tinggkatan Polres/Polrestabes untuk dapat memberikan pelayanan yang maksimal serta optimal di era new normal kepada masyarakat khususnya bagi kaum disabilitas (Humas Kementrian PANRB, 2020). Sebagai tindakan preventif pandemi Covid-19, Satpas Polrestabes Bandung juga menyediakan wastafel untuk pemohon mencuci tangan sebelum memasuki gedung dan di setiap loket dalam gedung Satpas telah tersedia hand sanitizer.

Komunikasi yang dibangun oleh petugas pelayanan SIM Satpas Polrestabes Bandung kepada pemohon SIM juga dinilai sudah baik dalam memberikan arahan mengenai prosedur pembuatan SIM. Kecakapan petugas dalam memahami keinginan masyarakat akan mempermudah dalam proses pemberian pelayanan itu sendiri, hal tersebut dapat membangun kesan yang positif yang akan menumbuhkan sikap simpatik dari masyarakat yang dilayani (Nurdin, 2019).

\section{Reliability (Kehandalan)}

Berdasarkan hasil pengamatan di lapangan dan wawancara yang dilakukan penulis, adanya SOP (Standar Operasional Prosedur) yang jelas mengenai proses pembuatan SIM di Satpas SIM Polrestabes Berdasarkan hasil pengamatan di lapangan dan wawancara yang Bandung juga telah disusunnya Maklumat Kapolrestabes Bandung Nomor: Kep/60/VIII/2020 tentang Pelayanan Penerbitan Surat Izin Mengemudi (SIM). Hal tersebut sebagai bentuk dilaksanakannya standar pelayanan prosedur berdasarkan Undang-Undang Nomor 22 Tahun 2009 tentang Lalu Lintas Dan Angkutan Jalan serta Perkap No. 9 Tahun 2012 tentang Surat Izin Mengemudi (Satlantas Polrestabes Bandung, 2021). Pentingnya memiliki standar pelayanan yang jelas sebagai pedoman petugas dalam melayani pengguna layanan, sebab dengan mengacu pada standar pelayanan, saat proses pelayanan berlangsung dapat berjalan dengan lebih baik agar tercapainya tujuan pelayanan (Abdussamad, 2019).

Sejalan dengan hal tersebut, bahwa standar pelayanan harus dimiliki oleh setiap penyeleggara pelayanan publik sebagai patokan juga pedoman yang wajib dipatuhi dan dilaksanakan oleh penyelenggara pelayanan, sebagai pedoman bagi penerima pelayanan saat proses pengajuan permohonan, serta menjadi instrumen kontrol masyarakat atas kinerja penyelenggara pelayanan. Selain itu, standar pelayanan yang disusun serta ditetapkan harus memperhatikan kondisi lingkungan serta kebutuhan yang disesuaikan dengan jenis, karakteristik, dan sifat layanan (Hardiansyah, 2018).

Di era Covid-19, Satpas Polrestabes Bandung juga telah memiliki SOP dalam masa Adaptasi Kebiasaan Baru (AKB) yang bertujuan untuk meningkatkan penerapan protokol kesehatan dalam kondisi new normal agar terciptanya kehidupan yang produktif dan aman, sebagai pencegahan penyebaran virus Covid-19, serta terwujudnya tertib administrasi pelayanan dalam penerbitan SIM yang transparan, efektif, efisien, dan akuntabel pada masa pandemi Covid-19 (Satlantas Polrestabes Bandung, 2021).

Adapun petugas pelayanan SIM Satpas Polrestabes Bandung telah mencerminkan kemampuan atau kinerjanya dengan baik dalam memberikan pelayanan sesuai dengan standar pelayanan dan SOP yang berlaku, serta menguasai instrumen pada proses pelayanan. Namun, belum seluruh petugasnya bersertifikat. Sementara itu, salah satu bentuk kompetensi pelaksana yakni memiliki sertifikat pendidikan kejuruan (Peraturan 
Menteri PANRB No. 15 Tahun 2014). Meskipun demikian, seluruh petugas pelayanan SIM telah dibekali basic skill dalam memberikan pelayanan administrasi SIM.

Akan tetapi, setiap penyelenggara pelayanan publik menginginkan agar dalam pemberian pelayanan, petugas pelayanan semaksimal mungkin berupaya untuk menghasilkan mutu hasil kerjanya setinggi mungkin (Nurdin, 2019). Karena rendahnya mutu hasil kerja dan pelayanan kepada masyarakat dapat diakibatkan oleh tingkat pengetahuan serta keterampilan yang minim. Oleh karena itu, upaya yang dapat dilakukan untuk meningkatkan mutu kerja petugas pelayanan SIM dengan penyelenggaraan pendidikan serta pelatihan baik teknik maupun fungsional. Berkenaan dengan kualitas pelayanan publik, bahwa kemampuan petugas berperan sangat penting dalam menentukan kualitas pelayanan tersebut (Saputro, 2015).

Responsiviness (Daya Tanggap)

Ketanggapan merupakan salah satu dimensi dalam mengukur kualitas pelayanan publik yang berkenaan dengan pemberian pelayanan secara tepat dan cepat serta responsif terhadap segala keinginan, masukan, dan kritikan masyarakat (Taufiqurokhman \& Satispi, 2018). Berdasarkan hal tersebut, indikator dalam dimensi daya tanggap yaitu pelayanan cepat dan tepat, serta penanganan keluhan masyarakat.

Dari hasil wawancara yang dilakukan dengan petugas Satpas Polrestabes dan pemohon SIM, dapat disimpulkan bahwa pelayanan yang diberikan sudah berjalan dengan tepat dan cukup cepat dikarenakan pandemi Covid-19, pemohon SIM tidak sebanyak saat kondisi normal atau sebelum adanya pandemi. Di samping itu, Satpas Polrestabes Bandung dalam penanganan pengaduan atau keluhan pemohon SIM dapat dikatakan sudah berjalan dengan maksimal. Dimana telah disediakan ruang pelayanan pengaduan baik penerimaan pengaduan secara langsung ke petugas pelayanan pengaduan sebagaimana pada Gambar 3, juga penerimaan melalui elektronik seperti melalui aplikasi WhatsApp, e-mail, media sosial. Instagram sebagai salah satu sosial media yang berguna untuk menebarkan informasi, juga menjadi salah satu bentuk layanan pengaduan. Dalam implementasi pelayanan publik oleh pemerintah dengan segala fasilitasnya demi terciptanya kepuasan masyarakat, dengan itu melalui pengaduan masyarakat baik secara langsung maupun tidak langsung akan berpengaruh kepada kualitas pelayanan publik yang dijalankan pemerintah (Sabeni \& Setiamandani, 2020).

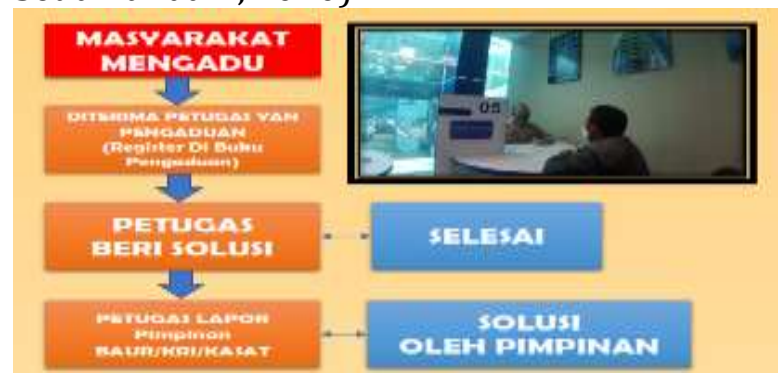

Gambar 3 Tahapan Penanganan Pengaduan Masyarakat

Sumber: Polrestabes Bandung, Tahun 2021

\section{Assurance (Jaminan)}

Jaminan berkaitan dengan sikap atau perilaku petugas pemberi layanan dalam menyakinkan kepercayaan masyarakat, serta dapat memberikan rasa aman. Indikator pada dimensi jaminan berkenaan dengan penelitian ini yaitu kemampuan petugas dalam memberikan kepercayaan dan perasaan aman pada masyarakat serta dapat memberikan kepastian ketepatan waktu, legalitas pelayanan, serta kepastian biaya pelayanan.

Berdasarkan hasil wawancara dan observasi peneliti di lapangan, dapat disimpulkan bahwa Satpas Polrestabes Bandung berupaya semaksimal mungkin dalam memberikan pelayanan yang aman dan nyaman meski di tengah pandemi Covid-19. Hal tersebut ditunjukan dengan penerapan protokol kesehatan yang ketat. Sebagaimana ditunjukan pada Gambar 1 dan Gambar 4, petugas rutin melakukan fogging disinfektan pada setiap ruangan di Gedung Satpas Polrestabes Bandung sebagai tindakan pencegahan penyebaran virus Covid-19. Selain itu, pemohon SIM wajib untuk diukur suhu badannya dan mencuci tangan terlebih dahulu sebelum memasuki gedung. 


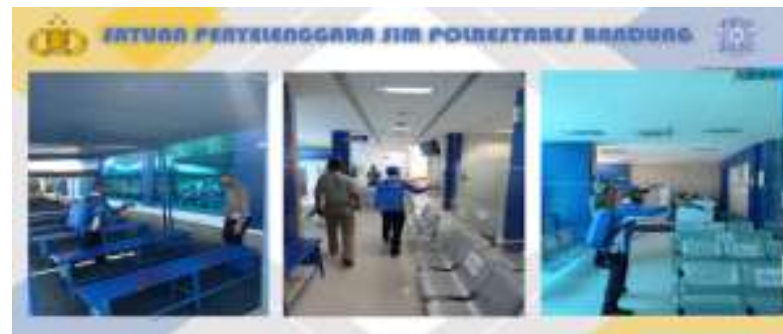

Gambar 4 Penyemprotan Disinfectan di Satpas Polrestabes Bandung

Sumber: Polrestabes Bandung, Tahun 2021

Menurut Zeithaml (Hardiansyah, 2018) untuk mengukur kualitas pelayanan publik, berkaitan dengan adanya jaminan ketepatan waktu, jaminan legalitas pelayanan, serta kepastian biaya pelayanan. Sejalan dengan hal tersebut, Satpas Polrestabes Bandung tidak dapat memberikan jaminan ketepatan waktu sesuai dengan yang tercantum dalam standar pelayanan. Hal tersebut dikarenakan melihat kondisi dan situasi yang terjadi seperti banyaknya pemohon pelayanan pembuatan SIM dan sistem yang beroperasi online atau offline. Berkaitan sistem pelayanan yang merupakan kesatuan utuh dari suatu rantaian pelayanan yang terhubung satu sama lain, jika salah satu bagian dari suatu sistem pelayanan tersebut mengalami gangguan maka dapat mengganggu keseluruhan pelayanan tersebut (Saputro, 2015).

Berkenaan dengan jangka waktu pelayanan yang tertuang dalam SOP, hal tersebut tidak dapat dijadikan patokan bahwa untuk pembuatan SIM sudah pasti selesai, contoh dalam 1 jam. Oleh karena itu, jangka waktu pelayanan pembuatan SIM yang tertulis dalam standar pelayanan Satpas Polrestabes Bandung hanya dapat dijadikan sebagai estimasi, tidak dapat dijadikan sebagai patokan.

Sebagaimana hal tersebut, bahwa tidak adanya kepastian ketepatan waktu dapat mempengaruhi pada pemberian pelayanan yang cepat. Dimana masyakarat mengharapkan pelayanan yang diberikan oleh aparat pemerintah berjalan dengan cepat dan membutuhkan kejelasan berapa lama waktu yang diperlukan untuk pelayanan tersebut selesai secara tuntas (Nurdin, 2019).

\section{Empathy (Empati)}

Sikap tegas dan ramah juga penuh perhatian dari pemberi layanan terhadap penerima layanan merupakan bentuk dari empati (Taufiqurokhman \& Satispi, 2018). Masyarakat sebagai penerima pelayanan mengharapkan dalam proses pelayanan mendapatkan perlakuan yang hangat dan bersahabat (Nurdin, 2019).

Adapun dari hasil observasi dan wawancara, petugas pelayanan SIM Satpas Polrestabes Bandung sudah memberikan pelayanan dengan humanis, ramah, menerapkan 5S (senyum, salam, sapa, sopan dan santun) dengan baik, memberikan perhatian penuh kepada pemohon SIM dengan diberikannya toleransi bagi yang terkena Covid-19, serta mendahulukan pemohon SIM yang membawa anak, lanjut usia, dan penyandang disabilitas. Di samping itu, sebagai bentuk kepedulian petugas pelayanan SIM Satpas Polrestabes Bandung terhadap pemohon SIM yang gagal dalam test diberikan kesempatan untuk mengulang hingga dinyatakan lulus seluruh testnya. Bentuk kepedulian petugas dalam memberikan perhatian dan mengutamakan kebutuhan masyarakat akan mendorong terciptanya kualitas pelayanan publik yang dapat menumbuhkan rasa kepuasan pada masyarakat (Yayat, 2017).

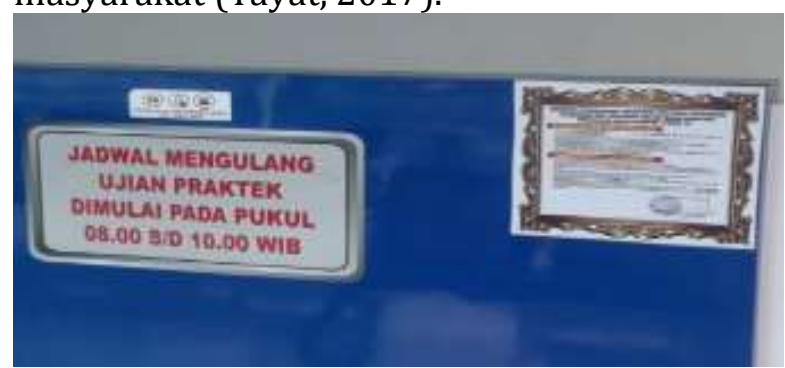

Gambar 5 Jadwal Mengulang Ujian Praktek

Sumber: Polrestabes Bandung, Tahun 2021

\section{SIMPULAN}

Berdasarkan hasil pembahasan di atas dapat ditarik kesimpulan bahwa kualitas pelayanan publik dalam pembuatan Surat Izin Mengemudi (SIM) di era Covid-19 pada Satpas Polrestabes Bandung tahun 2020 yang diukur berdasarkan lima dimensi yang meliputi tangible (berwujud), reliability (kehandalan), responsiviness (daya tanggap), assurance (jaminan), dan empathy (empati) secara umum sudah berjalan dengan optimal. Namun demikian Satpas Polrestabes Bandung tidak dapat memberikan jaminan kepastian waktu, karena berkaitan dengan jumlah pemohon SIM 
dan sistem online atau offline yang dapat mempengaruhi daya tanggap dalam pemberian pelayanan yang cepat.

\section{DAFTAR PUSTAKA}

Abdussamad, J. (2019). Kualitas Pelayanan Publik Di Kantor Dinas Kependudukan Dan Catatan Sipil Kabupaten Gorontalo. Publik: Jurnal Manajemen Sumber Daya Manusia, Administrasi Dan Pelayanan Publik, 6(2), 73 82. https://doi.org/10.37606/publik.v6i2.6

Bandung Berita. (2020, November 5). Dimasa Pandemi, Polrestabes Bandung Batasi Pemohon SIM. Bandungberita.Com. https://bandungberita.com/dimasapandemi-polrestabes-bandung-batasipemohon-sim/\#.YT5Bqp0zbIV

Creswell, J. W. (2019). Research Design Pendekatan Metode Kualitatif, Kuantitatif, dan Campuran (Edisi 4). Pustaka Pelajar.

Handoyo, E. (2012). Kebijakan Publik. Widya Karya.

Hardiansyah. (2018). Kualitas Pelayanan Publik Konsep Dimensi Indikator dan Implementasinya. Gava Media. http://repository.usu.ac.id/bitstream/1234 56789/23790/4/Chapter I.pdf

Hiplunudin, A. (2017). Kebijakan, Birokrasi, dan Pelayanan Publik; Tinjauan Kritis Ilmu Administrasi Negara. CALPULIS.

Humas Kementrian PANRB. (2020, June 15). Pelayanan Polri di Era Tatanan Normal Baru Harus Perhatikan Kaum Rentan. Menpan.Go.Id.

https://www.menpan.go.id/site/beritaterkini/pelayanan-polri-di-era-tatanannormal-baru-harus-perhatikan-kaum-rentan

Peraturan Menteri Pendayagunaan Aparatur Negara dan Reformasi Birokrasi RI No. 15 Tahun 2014 tentang Pedoman Standar Pelayanan, (2014).

Nurdin, I. (2019). Kualitas Pelayanan Publik (Perilaku Aparatur Dan Komunikasi Birokrasi Dalam Pelayanan Publik). Media Sahabat Cendekia.

Peraturan Kepala Kepolisian Negara Republik Indonesia No. 9 Tahun 2012 tentang Surat Izin Mengemudi, (2012).

Peraturan Wali Kota Bandung No. 37 Tahun 2020 tentang Pedoman Pelaksanaan Adaptasi Kebiasaan Baru Dalam Rangka Pencegahan dan Pengendalian Corona Virus Disease 2019 (Covid-19).

Undang-Undang Nomor 22 Tahun 2009 tentang Lalu Lintas dan Angkutan Jalan, (2009).

Putra, Y. A. A. P. P. (2021). Pengaruh Kasus Covid19 terhadap Angka Pembuatan SIM C di Polresta Kota Pontianak. MABIS, 12(1).
Putri, I. A. H. (2017). Pengaruh Kualitas Pelayanan Terhadap Kepuasan Publik dalam Pembuatan Surat Izin Mengemudi (SIM) di Kepolisian Resort Kutai Barat Tahun 2016. Ekonomia, 6(3). http://ejurnal.untagsmd.ac.id/index.php/EKM/article/view/318 5

Rasuanto, M. R. (2018). Kualitas Pelayanan Publik dalam Pembuatan Surat Izin Mengemudi (SIM) di Polrestabes Bandung Jawa Barat Tahun 2015 [Universitas Padjadjaran]. https://repository.unpad.ac.id/frontdoor/in dex/index/year/2020/docId/22004

Sabeni, H., \& Setiamandani, E. D. (2020). Pengelolaan Pengaduan Masyarakat Dalam Upaya Meningkatkan Kualitas Pelayanan Publik. JISIP: Jurnal Ilmu Sosial Dan IImu Politik, 9(1), 43-52. https://doi.org/10.33366/jisip.v9i1.2214

Saputro, H. E. (2015). Kualitas Pelayanan Publik. Jurnal Professional FIS UNIVED, 2(1).

Sarmini, A. (2019). Kualitas Pelayanan Surat Izin Mengemudi (SIM) Pada Kantor Satuan Lalu Lintas Polres Karimun. Soumatera Law Review, 2(2). http://ejournal.kopertis10.or.id/index.php/ soumlaw

Satlantas Polrestabes Bandung. (2021a). SOP Pelayanan Satpas Polrestabes Bandung dalam Masa Adaptasi Kebiasaan Baru Pandemi Covid 19.

Satlantas Polrestabes Bandung. (2021b). Standar Operasional Prosedur Proses Pembuatan SIM di Satpas SIM Polrestabes Bandung.

Suparman, N. (2017). Kualitas Pelayanan Izin Mendirikan Bangunan (IMB) Pada Badan Pelayanan Perizinan Terpadu dan Penanaman Modal (BPPTPM) Kabupaten Cianjur Provinsi Jawa Barat. Jurnal Borneo Administrator, 13(1), https://doi.org/10.24258/jba.v13i1.274

Suparman, N. (2021). Dampak Pandemi Covid-19 Terhadap Pengelolaan Keuangan Negara. Indonesian Treasury Review: Jurnal Perbendaharaan, Keuangan Negara Dan Kebijakan Publik, 6(1), 31-42.

Taufiqurokhman, \& Satispi, E. (2018). Teori dan Perkembangan Manajemen Pelayanan Publik. UMJ Press.

Yayat, R. (2017). Kualitas Pelayanan Publik Bidang Administrasi Kependudukan Di Kecamatan Gamping. Jurnal Ilmiah Magister Ilmu Administrasi (JIMIA), 2, 56-65. http://eprints.uny.ac.id/17523/1/SKRIPSI FULL.pdf

Yunita, N. S. (2018). Analisis Kualitas Pelayanan Terhadap Kepuasan Pelanggan (Studi Kasus Dalam Pelayanan Pembuatan SIM Di 
PUBLIKAUMA: Jurnal Ilmu Administrasi Publik UMA, 9 (2) (2021): 25-

Satlantas Medan) [Universitas Islam Negeri Sumatera Utara]. http://repository.uinsu.ac.id/id/eprint/517 1 